\title{
MNEs' Ownership Structure under Uncertainty: Explanations from TCE and Real Options Logic
}

\author{
Kenneth (Kyeungrae) $\mathrm{Oh}^{1}$ \\ ${ }^{1}$ School of Management, Penn State-Altoona, Altoona, Pennsylvania, USA \\ Correspondence: Kenneth (Kyeungrae) Oh, School of Management, Penn State-Altoona, Altoona, Pennsylvania, \\ USA. Tel: 1-814-940-3409. E-mail: kzo10@psu.edu
}

Received: December 16, 2016

Accepted: January 20, 2017

Online Published: January 26, 2017

doi:10.5539/ijbm.v12n2p67

URL: http://dx.doi.org/10.5539/ijbm.v12n2p67

\begin{abstract}
How does an MNE choose its ownership structure when it enters into transition nations where the level of corruption is largely high? This paper examines how uncertainty stemming from corruption affects an MNE's choice of governance forms using the data of 463 MNEs in 24 transition countries. Drawing on two theoretical perspectives such as TCE and real options logic, this study proposes two sets of competing hypotheses regarding firms' selection of ownership structure. Results show that TCE predictions have a better explanatory power on the choice of governance forms over those of real options logic as a whole. In particular, this study finds that an MNE is more likely to adopt wholly owned subsidiaries in highly arbitrary environment of corruption whereas they intend to cope with a joint venture form of governance under highly pervasive corruption environment. Consistently, an MNE which has more familiar with corruption tends to adopt a joint venture form of governance.
\end{abstract}

Keywords: transaction cost economics (TCE), corruption, real options, multinational enterprise (MNE), ownership structure, entry mode

\section{Introduction}

How does the nature of corruption affect multinational firms' strategic decision on ownership structure when they enter foreign markets in corrupt environments? In the field of international business, economics, and management, substantial attention has been paid to theoretical and empirical investigation on foreign direct investment and sequential decision on entry modes. Existing literature on corruption has also examined how the level of corruption is associated with the extent of foreign direct investment (Voyer \& Beamish, 2004; Habib \& Zurawicki, 2002; Sanyal, 2004, 2005; Mauro, 1998; Wei, 1997; Robertson \& Watson, 2004). However, relatively less studies have explored the relationship between corruption and entry modes which firms should subsequently consider once they decide a certain level of foreign direct investment. This study attempts to contribute this line of research by illuminating firms' heterogeneous features of strategic decision making on their ownership structure under the context of corrupt environments in transition economies where corruption may be conceived to be largely prevalent.

Extending the current literature on the mode-of-entry, this study particularly heeds on the effect of environmental uncertainty on entry modes at the firm level. The extant studies have identified numerous exogenous determinants that influence ownership structure such as political risk, national culture, and institutional environments (Davis et al., 2000; Delios \& Beamish, 1999; Henisz, 1999; Henisz \& Delios, 2001; Sharder, 2001; Rosenweig \& Singh, 1991; Yiu \& Makino, 2002). By incorporating corruption as a major factor of environmental uncertainty, this study attempts to draw more comprehensive picture for a firm's decision making on its ownership structure. Furthermore, drawing from transaction cost economics (TCE) and real option logic, this study sharply contrasts their competing explanations on the notion of uncertainty and its impact on a firm's choice of entry modes.

The motivation of the study stems from three different ways: first, it starts from the competing theoretical arguments on what the best mode of entry modes in uncertain environments is. Substantial literature on entry modes under uncertainty provides inconclusive and even conflicting results. Various theoretical lenses have been utilized to address this phenomenon: Transaction cost economics (TCE), Institutional theory, knowledge-based view, and real options logic. TCE, among them, would be one of the most influential, theoretical frameworks 
explaining the choice of appropriate governance structure (Carter \& Hodgson, 2006; Carroll \& Teece, 1999). TCE predicts that, in a highly uncertain environment, a firm is more likely to adopt highly committed and controlled forms of governance structure such as hierarchy or a wholly owned subsidiary (Anderson \& Gatignon, 1986; Williamson, 1975, 1985). More recent studies, however, challenge a TCE's prediction regarding external uncertainty. For instance, real option theory (Tong, Reuer, \& Peng, 2006; Tong \& Reuer, 2006), knowledge-based view (Kogut \& Zander, 1993), and institutional theory (Yiu \& Makino, 2002; Xu \& Shenkar, 2002; Xu, Pan, \& Beamish, 2004; Delios \& Beamish, 1999) generally propose opposite direction of predictions and explanations such that a firm may be more likely to adopt less committed and controlled forms of governance structure such as market contracts or joint venture in a highly uncertain environment. This study attempts to mitigate such conflicts by showing differential predicting power between two stark contrasting theoretical arguments from TCE and real options logic. Conspicuous difference between these two theories' prediction may be engendered from unique assumption and understanding regarding uncertainty. TCE regards uncertainty as a value-destroying factor by increasing transaction cost whereas real option logic conjectures that uncertainty plays a critical role in enhancing the value of options by securing upside gains. Accordingly, the research question is centered on how firms react or strategically behave against corruption environments, specifically with different ownership structures.

Second, existing literature on corruption has heavily influenced by the tradition of economics and business ethics. As such, there was a need for theoretical and empirical explorations for looking into corruption from the management perspective in which corruption would be defined as firm-specific phenomenon (Luo, 2004; Zahra, Priem, \& Rasheed, 2005; Ashford \& Anand, 2003; Gordon \& Miyaki, 2001). Likewise, research on corruption in economics has evolved into inquiries on endogenous corruption which are more concerned about supply-side of corruption rather than demand-side of corruption (Milovanovic, 2002; Blackburn et al., 2002; Barreto, 2000). Therefore, supply-side literature on corruption pays more attention to the role of firms and interaction between firms and governmental officials and thereby it explicitly reveals endogenous characteristics of corruption. This study intends to correspond to such stream of research by incorporating firms' active response and strategic actions to corrupt environments and by delineating heterogeneous features of firms' behavior on corruption with their decision on ownership structure.

Lastly, this study introduces a new finer-grained construct of corruption proposed by Rodriguez et al (2005). Rather than uni-dimensional measure of corruption, they argue that two-dimensional construct - pervasiveness and arbitrariness of corruption - better captures the complex features of corruption across countries. Indeed, while corruption is everywhere, it is not the same features. In this sense, this paper adopts this two-dimensional construct of corruption and empirically test whether it produces real differences in firms' choice of ownership structure.

\section{Literature Review}

\subsection{TCE Perspectives on the Choice of Entry Mode and Ownership Structure}

Transaction cost economics (TCE) is one of the most prominent and influential theoretical paradigms to explain appropriate governance structure spanning market to hierarchy as the alternative ways of contracts (Carter \& Hodgson, 2006; Carroll \& Teece, 1999). Applied domains of TCE logics encompass diverse disciplines such as economics, marketing, management, and international business (Williamson, 1999; Richman \& Macher, 2003). In international business field, in particular, TCE theory is quite dominant as a theoretical underpinning in addressing the crucial issue of entry mode choice and ownership structure when firms enter into foreign markets. Since Anderson and Gatignon's $(1986,1988)$ founding study has examined the entry mode choice from the view of TCE perspective, transaction cost approaches have triumphed over other competing explanations of firms' strategic choice of ownership governance for two decades. However, despite this salient presence of the theory, the debate has continued on the issues of its empirical validity and applicability (Perrow, 1981; Granovetter, 1985; Ghosal \& Moran, 1996; David \& Han, 2004). Several studies present inconsistent findings in empirical examinations of TCE theoretical arguments (David \& Han, 2004; Zhao et al., 2004; Carter \& Hodgson, 2006) even though they may implicitly acknowledge the theoretical achievement and compatibility of TCE. In fact, while 'asset specificity' has much of explanatory power (Williams, 2005) and the most consistent independent variable (David \& Han, 2004) among the relevant dimensions for describing transactions, the dimension of 'uncertainty' is quite mixed in predicting pertinent form of governance and its concept is suspected to be unclear. The original concept of uncertainty theorized by Williamson $(1975 ; 1985)$ is decomposed into external and internal uncertainty (Anderson \& Gatignon, 1986). However, given the two forms of its operationalization such as endogenous uncertainty such as partner opportunism and other behavioral issues, and exogenous uncertainty such as technology and volatility of environment, the predicted results are still pretty conflicting and 
inconclusive (David \& Han, 2004; Zhao et al., 2004; Carter \& Hodgson, 2006).

This study explores how MNEs strategically orchestrate their ownership structure when entering into the transition economies where may be usually conceived as highly uncertain and corrupt. According to the original thoughts on TCE by Williamson $(1975,1979,1983,1985)$, asset specificity, uncertainty, and frequency mostly determine transaction costs which discriminate MNEs' selection of governance mode by way of economizing these costs. Among these determinants of transaction costs, corruption environments are certainly one aspect of uncertainty factors. As discussed above, this study mainly concerns about exogenous uncertainty and explores how exogenous uncertainty affects MNEs' decision on feasible ownership structure in transition economies.

A central tenet of TCE is that the boundary of the firm would be determined by relative transaction cost between organizations and markets. Coase (1937) argues that firms will exist only in environments in which firms perform better than markets could (Gibbons, 1999). Likewise, TCE asserts that the ideal institutional form to govern transactions depends on the level of market imperfections plagued by transaction cost. As imperfections increase, markets become less attractive and organizations more attractive (Williamson, 1985). According to TCE, firms should focus on designing governance forms to avoid uncertainty to reduce transaction cost. In this logic, TCE claims that uncertainty may push a firm to adopt an internalized governance mechanism vis-à-vis markets for better control (Williamson, 1985). When it comes to MNEs' equity-based entry in foreign markets, MNEs naturally intend to minimize transaction costs intrigued by foreign business operation. In general, when MNEs would consider building an equity-based partnership, they may face two different kinds of transaction costs in terms of uncertainty. On the one hand, partners' behavioral uncertainty like opportunism would increase transaction costs such as monitoring, contracting, and others. On the other hand, firms also suffer from exogenous uncertainty in host countries such as cultural and institutional differences. In a given level of partners' behavioral uncertainty, firms are more likely to internalize their transactions to optimize transaction costs with hierarchical forms of governance as exogenous uncertainty becomes higher. Consistently, TCE predicts that given some degree of asset specificity, control becomes more desirable as uncertainty increases (Anderson \& Gatignon, 1986). Therefore, a firm will be more likely to adopt a high controlled form of governance such as hierarchy or a wholly-owned subsidiary in a high uncertain environment to minimize transaction costs.

\subsection{Real Options Logic of Governance Structure}

Prior research on the foreign entry mode, however, also provides different impact of exogenous uncertainty on the choice of governance structure in foreign markets. For instance, Gatignon and Anderson's (1988) study of foreign market entry shows that exogenous uncertainty has a negative relationship with more integrated form of governance such as wholly owned subsidiaries or vertical integration. Likewise, Hill and Kim (1988) claim that volatile environments drive firms to adopt less committed forms of governance rather than inflexible entry modes. Exogenous uncertainty such as market condition, cultural difference, institutional difference which leads to liability of foreignness, and technological change induces more flexible mode of foreign entry (Gatignon \& Anderson, 1988). Likewise, Henisz (2000) shows that as political hazard increases, minority-owned partnership becomes favored market entry mode. All results cited above countervail the predictions on ownership structure based on TCE arguments.

The staged roll-out of foreign investment is literally fitted with the crucial conditions for real options. MNEs' foreign investment can be characterized as (1) irreversibility (2) uncertainty over future rewards from the investment, and (3) some leeway about the timing of investment. Moreover, as Dixit and Pindyck (1994) claim, firms' foreign investment is very sensitive to volatility and uncertainty over the economic environment. Real option logic asserts that volatility and uncertainty probably increases the propensity towards establishing real options. Generally, the role of uncertainty is elevating the value of growth options that a firm purchases from its initial market entry, which is decisively distinct to the view of TCE on uncertainty. Under high uncertainty, a small investment at the beginning allows for a better acquisition of information and curbs the risk of capital to be lost, while it preserves the flexibility of investing more at a later stage. It works as a call option on a larger investment (Buckley \& Casson, 1998).

From the perspective of real options theory, joint ventures are viewed as flexible and attractive compared to wholly owned subsidiaries since they can reduce risk from uncertainty in host countries with lower initial capital investments (Reuer \& Leiblein, 2000). Less-committed forms of governance like joint ventures can limit their initial investments and then increase commitments once they can realize the future value (Kogut, 1991). Therefore, values of options are associated with reducing the risk of making commitment (Chatterjee et al., 1999). By this real options' logic, a firm may reduce downside risk by adopting a less committed forms of governance in a highly uncertain environment. 
Based in such real options logic, this study expects that firms suffering from uncertainty in host countries such as cultural and institutional differences would adopt more flexible forms of ownership with local partners (Yiu \& Makino, 2002; Xu \& Shenkar, 2002; Xu et al., 2004). Corruption may play a role of enhancing the extent of exogenous uncertainty and risks. MNEs attempt to form a partnership in a way of curtailing downside risks while securing upside potentials. Indeed, corruption as an aspect of institutional environment can be conceived of host country's political and economic risk and uncertainty. Firms tend to reduce the level of host country risks by utilizing lower ownership modes in host countries as political and economic risk and uncertainty increase (Delios and Beamish, 1999; Anderson and Gatignon, 1986; Hennart, 1988; Hill et al., 1990).

\section{Theory and Hypotheses Development}

Corruption is one of important institutional constraints (North, 1990) when MNEs enter into a foreign country particularly in transition economies where corruption is pervasive and arbitrary as a whole. Previous literature on corruption consistently presents the detrimental effects of corruption on economic development and foreign direct investment (FDI) inflows (Mauro, 1995; Habib \& Zurawicki, 2002; Demsetz, 1968; Shleifer \& Vishny, 1993; Ades \& Di Tella, 1999; Campos et al., 1999; Voyer \& Beamish, 2004; Wei, 2000). However, little attention has paid to the question of how MNEs respond to corruption at a firm level, particularly with ownership structure. Very exceptionally, Smarzynska and Wei (2000) and Uhlenbruck et al. (2006) investigate the impact of corruption in a host country on foreign firms' choice of ownership structure. In fact, strategic decisions such as foreign investments and entry-mode choice are made at the firm level and thereby incorporating firm-specific decisions on ownership structure under various level of uncertainty enhances understandings of MNEs' foreign expansion. Drawing upon transaction cost economics and real options logic on the entry strategy of MNEs, this study examines the appropriate forms of ownership structure under corruption environment by proposing two sets of competing hypotheses predicted by two distinct theories.

\subsection{The Choice of Entry Mode in the Arbitrariness of Corruption}

Corruption is prevalent everywhere but it is not the same features everywhere (Rodriguez et al., 2005). Therefore, the challenges firms confront in entering foreign countries would be different and appear wide variations across host countries they enter. In this sense, recent research on corruption becomes much appreciate the features of endogenous corruption, corruption per se and firms' interaction with corruption. Correspondingly, bi-dimensional constructs of corruption - pervasiveness and arbitrariness of corruption - would more precisely capture the complex features of corruption than the single measure of corruption (Rodriguez et al., 2005). Consistently, Shleifer, and Vishny (1993) theorize this line of argument and Wei (1997) examines empirically in that firms' experience in a corrupt environment is substantially different not only by the level of corruption but also by the uncertainty associated with corrupt transactions (Rodriguez et al., 2005). In particular, MNEs' strategic selection of entry mode may better reflect heterogeneous features of firms' behavior under this bi-dimensional construct of corruption environments than single index measure of corruption.

Rodriguez et al. (2005) conceptualize arbitrariness of corruption as the degree of uncertainty associated with corrupt transaction in a given state. Under the environment of highly arbitrary corruption where firms suffer from the uncertainty of the size, target, and number of corrupt payments necessary to get things done, an MNE hardly figures out complexity of the institutional environment associated with corruption. Indeed, an MNE confronts multiple corrupt governmental officials, perplex corrupt customs, and conflicting institutional pressures. In such arbitrary environment, an MNE has an enduring trouble with understanding and adapting local corruption. Thus, arbitrary corruption encourages firms to seek alternative way of securing upside gains as well as of reducing downside risks through a partnering with local firms. Expanding firms' externalities with a form of joint venture, firms can effectively develop coping capabilities to deal with uncertain and arbitrary corruption (Rodriguez et al., 2005). As such, an MNE entering foreign countries where corruption is arbitrary is highly likely to adopt a local partner to reap potential opportunities in the future and to reduce risk associated with return uncertainty. Such a joint venture form of governance structure countervails the disability of an MNE to address arbitrary local corruption. Likewise, Anderson and Gatignon (1986) propose that firms are better off utilizing low control and ownership modes such as joint ventures instead of wholly-owned subsidiaries in externally uncertain and volatile environments.

In real options logic, higher uncertainty introduces higher value of options. Through options, firms can reduce the strategic risk of making commitment under uncertainty (McGrath \& Nerkar, 2004). By definition, a high level of arbitrary corruption nourishes opportunistic behaviors with high uncertainty and in turn hurts trust among stakeholders (You \& Khagram, 2005). Such uncertain environment, by real option logic, is more likely to invite a small scale of investment upfront and to induce a follow-on large scale investment after figuring out 
uncertainty. By this logic, in a highly arbitrary corruption environment, firms attempt to access to the opportunities of foreign market with less committed forms of investments such as joint ventures rather than wholly owned subsidiaries in order to reduce the risk and unpredictability from arbitrary corruption and to capitalize future values (Reuer and Leiblein, 2000). Similarly, Miller and Folta (2002) show that there may be value in deferring of entry timing in the presence of exogenous uncertainty. Accordingly, I hypothesize:

Hypothesis 1a: The higher the arbitrariness of corruption in a host country, the more likely the MNE will choose a less committed form of governance such as a joint-venture over a wholly-owned subsidiary.

On the other hand, TCE framework predicts the exactly opposite direction such that firms exposed to high exogenous uncertainty such as arbitrary corruption may intend to adopt highly controlled forms of governance structure in order to reduce the level of host country risk and uncertainty (Anderson \& Gatignon, 1986). A high arbitrary corruption denotes a high level of ambiguity and unpredictability of corrupt transactions, which often leads to high transaction cost. Very often, firms need to do multiple payments to the same or different officials for a deal because of unorganized corruption in highly arbitrary corruption (Shleifer \& Vishny, 1993; Rodriguez et al., 2005). When corruption is arbitrary, laws and policies are subject to capricious and are varied in interpretation by judges and governmental officials (Ahlstrom \& Bruton, 2001). It provides a fertile ground for opportunism and leads to inefficient transaction (Oldenbrug, 1987). Moreover, a high arbitrary corruption may cause a collapse of trust between transaction agents. Although Williamson $(1994$, p114) maintains that trust is irrelevant to commercial exchange, it may be critical to reduce transaction costs in the absence of appropriate economic institutions like in transition economies (Fukuyama, 1996; Coleman 1994).

Taken all together, a high arbitrary corruption functions toward increasing transaction costs and it, in turn, affects firms' choice of governance modes as a way of minimizing transaction costs. Likewise, Williamson (1975) argues that as the degree of uncertainty increases, hierarchy (or internal organization) becomes a more attractive form of managing economic transactions. Adopting higher ownership structures can be justified as lowering transaction costs in host countries with greater corruption and uncertainty by internalizing transactions. In fact, higher arbitrary corruption induces greater transaction costs and thus firms attempt to mitigate heightened transaction costs with high committed modes of governance structure which allow to more security from spillover and endogenous uncertainty such as partners' opportunism. Therefore, I propose:

Hypothesis 1b: The higher the arbitrariness of corruption in a host country, the more likely the MNE will choose a wholly-owned subsidiary over a joint venture.

\subsection{The Choice of Entry Mode in the Pervasiveness of Corruption}

Unlike arbitrariness of corruption, the pervasiveness of corruption substantially reduces the extent of uncertainty involved in corrupt transactions. Here, I define the pervasiveness of corruption as the average firm's likelihood of encountering corruption in its normal interactions with state officials, following Rodriguez et al.'s (2005) definition. By this definition, this study conjectures that the pervasive corruption indicates lower level of uncertainty associated with corruption compared to the arbitrariness of corruption, although it still invokes some level of uncertainty to MNEs. A lowered uncertainty by a high pervasiveness of corruption makes transaction less costly and allows firms to regard corrupt payments as an explicit tax (Wei, 1997). When corruption is pervasive, an MNE may shortly understand mechanism of corruption in a given country and in turn reduces complexity and uncertainty intrigued by corruption. In such environments, corruption could be socially valid and regularized in transactions, which lead to lower level of risk and uncertainty. Likewise, the pervasiveness of corruption tends to reduce complexity of corruption environments and adjustment costs are rapidly dropped (Rodriguez et al., 2005). Therefore, benefits of local partners in pervasive corruption would relatively low over those in arbitrary corruption and thereby an MNE investing foreign countries where corruption is pervasive may enjoy more freedom of entry-mode choice. According to real options logic, given such situations, an MNE is more likely to adopt highly controlled and more committed forms of ownership structure such as wholly-owned subsidiaries since it indicates the lower level of the risk and less extent of partners' behavioral opportunism (Folta \& Miller, 2002). In a lower level of uncertainty, the value of multi-stage sequential investments and deferring options by partnering with local firms may be significantly depreciated. In fact, lower level of uncertainty reduces the value of options (Bowman \& Hurry, 1993). Accordingly, there is a lower degree of downside risk and thereby firms are more likely to increase their levels of commitment. Therefore, I propose:

Hypothesis 2-a: The higher the pervasiveness of corruption in a host country, the more likely the MNE will choose a wholly-owned subsidiary over a joint venture.

By contrast, TCE perspective insists that lower uncertainty invites market forms of governance structure. When corruption is prevalent, managers of an MNE perceive less uncertainty. Indeed, in a high pervasiveness of 
corruption, firms recognize corruption as being regularized and thus they may figure out its cost and benefits in corruption transactions. Therefore, firms may understand its mechanism and control over the corruption environment. Consequently, they do not seem to be involved in high risk and high cost situations when they engage in corrupt behaviors. A certain environment like pervasiveness of corruption is less likely to encounter unanticipated contingencies that require renegotiation. In this condition in which uncertainty is relatively low, firms are more likely to organize their activities through markets rather than organizations (hierarchy) to minimize their transaction cost. As Williamson (1991) claims, this study posits that markets and hierarchies are not discrete alternatives, rather they are end points of a continuum with possibilities of hybrid forms in between. Here I think of an MNE that enters into transition countries with a certain percentage of ownership. In a given condition, therefore, an MNE tends to select more market forms of governance such as a minority-type of joint venture or a joint venture in a high pervasiveness of corruption. Accordingly, I hypothesize:

Hypothesis 2-b: The higher the pervasiveness of corruption in a host country, the more likely the MNE will choose a joint venture over a wholly-owned subsidiary.

\subsection{Entry-Mode Choice in a Corruption Distance between the Host and the Home Country}

Besides the absolute level of corruption in host countries, the relative level of corruption between the host and the home country really matters. As Kostova and her colleagues (Kostova \& Roth, 2002; Kostova \& Zaheer, 1999) point out, an MNE mostly experiences dual institutional pressure from both the home and the host country if there is a substantial difference in institutional norms and practices between the two. Indeed, regardless of the certain level of corruption in host countries, an MNE's perception of and adapting capabilities against local corruption would be also determined by their experience in home countries. Hypothetically, a Russian MNE may have more knowledge and experience over an MNE from developed countries as to how to deal with corruption in the home country and thereby they can be relatively easier to get familiar to the mechanism of locally idiosyncratic corruption in transition economies. By contrast, an MNE coming from the countries having strong legal constraints against corruption such as the Foreign Corrupt Practices Act in U.S. severely suffers from highly pervasive and arbitrary corruption because of conflicting dual institutional pressures and less familiarity of it. To overcome such confliction and uncertainty, an MNE may choose less committed modes of ownership structure (Rodriguez et al., 2005). That is why Rodriguez et al. (2005) propose that firms' decision to enter and to choose proper ownership structure is determined by the institutional distance of corruption between an MNE's home and host country. The greater the institutional distance of corruption, the greater an MNE suffers from conflicting institutional pressures between the home and the host country, which uncertainty and risk in host countries, and transaction costs in host country operations (Kostova \& Roth, 2002; Davis et al., 2000). Considering the context of this study, I postulate that an MNE coming from a more corrupt country may be more familiar with corruption and thereby may be better off dealing with, adapting to, and responding to corruption in host countries. It means that an MNE from developed countries will expose a higher level of uncertainty and risk, comparing with an MNE coming from more corrupt countries. Based on this reasoning, real options logic may predict an opposite way of choice in that an MNE coming from less corrupt countries is more likely to choose less committed forms of ownership structure when it enters into highly corrupt countries. Exogenous uncertainty from institutional distance may be similar to the case of liability of foreignness in the host country. By the same logic, cultural distance is also negatively associated with a market entry by equity (Tsai \& Cheng, 2002; Delios \& Henisz, 2003). Likewise, Reuer (2002) finds that under high cultural distance, foreign investors seek to hold real options. Investors may also tend to keep these options longer alive than in countries that are culturally similar. Like cultural distance, institutional distance of corruption plays a significant role in increasing uncertainty to which an MNE encounters in transition economies. Such heightened uncertainty enhances the value of options to defer and to stage investments and thus firms are more likely to choose less committed forms of governance until uncertainty will be resolved. Similarly, McDonald and Siegel (1986) demonstrate that in the presence of uncertainty it can be optimal to defer irreversible investments. Hence, I propose:

Hypothesis 3-a: When the FDI is initiated by a firm from a less corrupt country, an MNE will choose a joint venture over a wholly-owned subsidiary in a host country in transition economies.

By contrast, TCE arguments may predict that if there is a high distance between the home and the host country regarding the extent of corruption, an MNE are more likely to confront high risk and uncertainty, and in turn it is more likely to choose wholly owned subsidiary in a host country in transition economies. Since Hymer's (1960, 1976) theorization, costs of doing business abroad serve as a key factor to motivate research on MNEs' internationalization (Buckley \& Casson, 1976; Caves, 1982; Dunning, 1977; Hennart, 1982). Extending this notion, Zaheer and colleagues compatibly conceptualize a liability of foreignness which MNEs face in host countries (Kostova \& Zaheer, 1999; Zaheer, 1995; Zaheer \& Mosakowski, 1997). Although there is subtle 
difference between the two (Note 1), these concepts stress cost generating factors of doing business abroad. In addition to economic costs, the social costs arise from unfamiliarity of culture and institutional norms and practices, discriminatory regulations, and lack of relational networks (Eden \& Miller, 2004). In particular, the institutional distance is regarded as the key driver behind a liability of foreignness (Eden \& Miller, 2004). All these costs are inherently associated with uncertainty in host countries and MNEs' ownership structure is conceived as a way of reducing such economic and social costs. When institutional distance of corruption is greater, an MNE is more likely to suffer from a liability of foreignness and uncertainty from it. It may cause higher transaction costs in doing a business in transition countries. In this reason, an MNE may intend to reduce such transaction costs through more hierarchical form of governance such as wholly owned subsidiary. Accordingly, I hypothesize:

Hypothesis 3-b: When the FDI is initiated by a firm from a less corrupt country, an MNE will choose wholly owned subsidiary over a joint venture in a host country in transition economies.

\section{Empirical Research}

\subsection{Data Collection}

The main dataset is coming from the Business Environment Enterprise Performance Survey (BEEPS) conducted by World Bank. In addition, I compile other dataset such as the World Business Environment Survey (WBES), the database of World Development Indicators (WDI), and Governance Indicators (GI) with the main dataset. The general description of this dataset is that it was conducted through face-to-face interviews with firm managers or owners in site visits during the period June through August 1999 in the 24 European transition countries. The total sample of dataset is 4104 . But, since my research question is that how the features of corruption in transition economies affect foreign firms' (Multinational Enterprise) choice of ownership structure, I will filter the dataset to obtain only foreign firms, which invest transition economies and own, at least, some equity in foreign firms in host countries, including wholly owned subsidiaries. The final data consists of 463 observations.

\subsection{Methodology: Model Specification}

The model describes MNEs' decision to take a certain ownership structure, here either a wholly owned subsidiary or a joint venture, in a host country. Based on existing literature, the study examines both 80 percent and 95 percent model as a cut-off threshold which differentiates between two distinct forms of governance. Although ownership structure is continuous across zero to one hundred, most studies operationalize it as discrete modes of entry or ownership structure - joint venture, wholly owned subsidiaries, and acquisition (Kogut and Singh, 1988). Early research uses 95 percent as the cut-off point to distinguish joint venture from wholly owned subsidiaries (Stopford \& Wells, 1972; Anderson \& Gatignon, 1986; Gomes-Casseres, 1989; Hennart, 1991; Padmanabhan \& Cho, 1996). More recent studies take 80 percent as a threshold (Makino and Beamish, 1998; Yiu \& Makino, 2002). Distinctively, Henisz (2000) categorizes it into minority-owned and majority-owned joint venture with 50 percent as classification criteria (Xu et al., 2004). Based on such prior research, here I investigate and present three different ways of classification - 95 percent, 80 percent and four discrete forms of ownership such as minority-owned, J/V, majority-owned, and wholly owned subsidiaries. In fact, 49-51 percent of joint venture form would be critically, discretely different from 50-50 percent joint venture from with respect to the level of control and management discretion.

\subsubsection{Logit and Probit Regression Model Specification}

Ownership $_{i c}=1$ if Ownership ic $_{\text {O }}>80$ (Model 1) or 95 (Model 2) (Wholly owned subsidiary)

\section{0 , otherwise (Joint venture)}

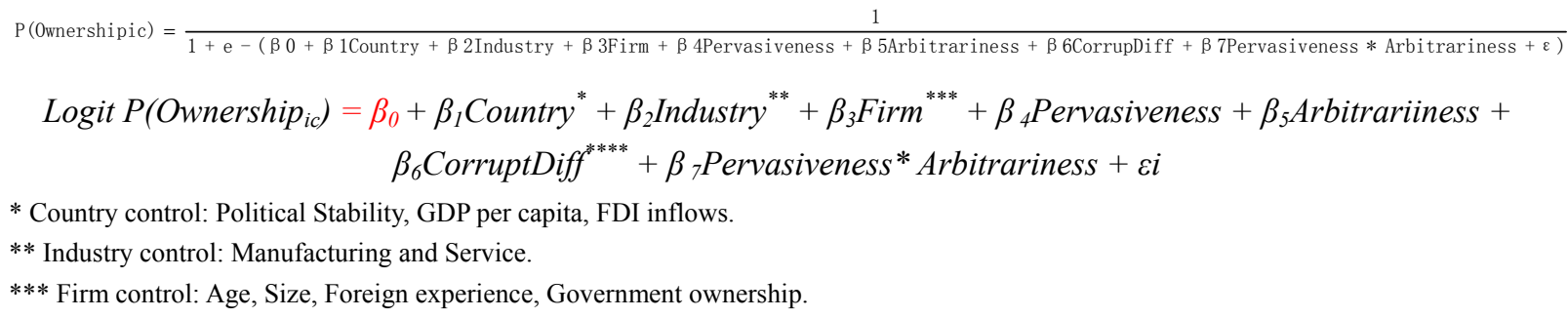

** Industry control: Manufacturing and Service.

*** Firm control: Age, Size, Foreign experience, Government ownership.

4.2.2 Model Specification for Multinomial Logit Regression Model

As an alternative model, I also propose a four-discrete multinomial logit model. Ownership structure of MNEs in 
foreign countries is classified into four discrete categories: minority-owned joint ventures, 50-50 joint ventures, majority-owned joint ventures, and wholly owned subsidiaries. As Williamson (1991) argues, these different governance structures vary discretely in terms of incentive intensity, administrative controls, and contract law regime. Accordingly, I analyze it with multinomial logit regression rather than ordered logit regression.

$$
\begin{aligned}
& \operatorname{Prob}\left(Y_{i}=j / X_{i}\right)=e^{\beta^{\prime} i X i} \quad j=1,2,3,4 \\
& 1+\sum_{k=2}^{4} e^{\beta ' k X i}
\end{aligned}
$$

$\mathrm{J}=1$ (Minority-owned Joint Venture), 2 (Joint Venture), 3 (Majority-owned JV), 4 (Wholly-owned Subsidiary, WOS).

\subsection{Description of Variables}

\subsubsection{Dependent Variable}

Ownership structure of MNEs in transition economies is adopted as a dependent variable. It is captured by a dummy variable, Joint Venture (JV) or wholly owned subsidiaries (WOS). Joint venture is coded as 0 and 1 otherwise. Based on literature of the entry strategy, I set up 80, or 95 percent of equity share as the threshold for distinguishing two types of ownership structure (Yiu and Makino, 2002). As for the alternative model, a dependent variable is set up by four discrete variables: minority-owned joint ventures ( 1 to 49 percent of ownership), 50-50 joint ventures, majority-owned joint ventures (51 to 99 percent of ownership), and wholly owned subsidiaries.

\subsubsection{Independent Variables}

Pervasiveness of corruption is measured by the extent of occurrence of corruption in a country, which indicates how much corruption pervades in business activities in dealing with government officials. Arbitrariness of corruption is specified as a concept of amount and interval unpredictability of effective bribery and uncertainty of expected result realized. They are captured by 6 interval scale in the BEEPS. Distance of corruption between the home and the host country is measured by the degree of difference in corruption level between home and host countries. If an MNE comes from more corrupt country than the host country, the case is coded as 1 and 0 otherwise.

\subsubsection{Control Variables}

I include several variables in the regressions to control for country, industry, firm level characteristics. Recurring to the association between economic and political development and the level of corruption of a country in previous studies, political stability (Wei, 2000; Smarzynska and Wei, 2000) is employed as one of control variables to partial out country-level effects. In literature on the entry-mode choice, political stability is widely perceived as a relevant control variable (Asiedu and Esfahani, 1998) by assuming its association with the extent of aspiration of foreign investment. I borrow the Kaufmann's political stability index from the Governance Indicators (Kaufmann et al., 2003), which is standardized measure ranged from -2.5 to 2.5. GDP per capita is selected as a variable for controlling for country effects. It is generally conceived as a proxy for a market size and thereby prior research also adopts it as a control variable (Wei, 2000; Voyer \& Beamish, 2004; Habib \& Zurawicki, 2002; Kobrin, 1976; Gomes-Casseres, 1989, 1990). The GDP per capita is obtained for the year of 1999 and from the WDI database provided by World Bank. FDI inflows are also included as a control variable since it reflects the degree of market restrictions and affects MNEs entry and the entry mode (Rajan \& Zingales, 2003; Uhlenbruck et al., 2006). This measure is drawn from WDI database, indicating that foreign direct investment is net inflows of investment to acquire a lasting management interest (10 percent or more of voting stock) in an enterprise operating in an economy other than that of the investor and it is calculated into the percentage of FDI inflows of GDP. Industry dummy variables are included in the regressions as control variables to account for industry differences in bribing behaviors and ownership structure. The study incorporates two categories for it: manufacturing and service. I also employ four firm level variables as a control variable: firm size, firm age, foreign experience, and government ownership. Firm size is measured by the number of employees of a firm. Past studies also use it as a control variable since it is reported to be associated with the pattern of investment by firms (Gatignon \& Anderson, 1986; Kogut \& Singh,1988; Agarwal \& Ramaswamin, 1992; Oxley, 1997). Firm age reflects its tenure since a firm is founded. I use the year of 1999 as a reference year, at which the survey is conducted. Since older firms would be more familiar with the institutions of corruption and potentially less suffer from corruption, I control for age. Foreign experience is considered as one of crucial variable to affect foreign investment and the entry mode in the field (Gatignon \& Anderson, 1986; Kogut \& Singh,1988; Gomes-Casseres, 1989, 1990; Hennart, 1991; Agarwal \& Ramaswamin, 1992; Oxley, 1997; Delios \& Henisz, 2000). I capture it through the number of countries in which MNEs operate their business. 
Government ownership indicates whether the firm has an amount of equity by the state or not. If a firm has a share owned by the state, it is coded as 1 and 0 otherwise.

\section{Results}

Table 1 presents means, standard deviations, and correlation coefficients of all variables in the analysis. Consistent with existing literature, foreign ownership is positively related with political stability, GDP per capita, and FDI inflows. Generally, since the coefficient levels of correlation seems not that high and no VIF is greater than 5 (Chatterjee \& Price, 1991), the data may not have problems related to multicollinearity. As for the multinomial logistic regression model, the study conducted the test for the assumption of independence of irrelevant alternatives (IIA) to show the independence of other three discrete forms of governance structure from minority-owned joint ventures. A Hausman test for IIA (Hausman \& McFadden, 1984) shows that the model of multinomial logit has no bias from IIA. It implies that the choice between any two ownership structures as alternatives is independent of another choice of alternatives.

Table 1. Descriptive Statistics and Pearson Correlation Coefficient

\begin{tabular}{|c|c|c|c|c|c|c|c|c|c|c|c|c|c|c|}
\hline Variables & Mean & S.D. & 1 & 2 & 3 & 4 & 5 & 6 & 7 & 8 & 9 & 10 & 11 & \\
\hline Foreign & 59.98 & 31.99 & 1.0000 & & & & & & & & & & & \\
\hline \multicolumn{15}{|l|}{ Ownership } \\
\hline 2. Political & .054 & .644 & 0.1613 & 1.0000 & & & & & & & & & & \\
\hline \multicolumn{15}{|l|}{ Stability } \\
\hline 3. GDP per & 2490 & 2027 & 0.1262 & 0.7413 & 1.0000 & & & & & & & & & \\
\hline \multicolumn{15}{|l|}{ Capita } \\
\hline 4. FDI Inflows & 4.32 & 2.96 & 0.2499 & 0.4168 & 0.1125 & 1.0000 & & & & & & & & \\
\hline 5. Industry & 0.52 & 0.50 & 0.1367 & 0.0230 & 0.0290 & 0.0769 & 1.0000 & & & & & & & \\
\hline 6. Firm Age & 10.66 & 16.79 & -0.0760 & 0.1859 & 0.2119 & 0.0564 & -0.1828 & 1.0000 & & & & & & \\
\hline 7. Firm Size & 4.22 & 1.69 & -0.1403 & 0.1658 & 0.1906 & 0.0529 & -0.4719 & 0.2595 & 1.0000 & & & & & \\
\hline 8. Foreign & 0.30 & 0.45 & 0.1210 & 0.0640 & 0.0280 & 0.1962 & 0.0671 & 0.0576 & 0.0146 & 1.0000 & & & & \\
\hline \multicolumn{15}{|l|}{ Operation } \\
\hline 9. Government & 1.81 & 0.38 & 0.2812 & -0.0366 & 0.0026 & 0.0230 & 0.2484 & -0.2361 & -0.3354 & 0.0328 & 1.0000 & & & \\
\hline \multicolumn{15}{|l|}{ Ownership } \\
\hline 10.Legal & 0.12 & 0.32 & -0.0095 & -0.0131 & -0.0576 & 0.0135 & 0.0776 & -0.0304 & 0.0129 & 0.0010 & 0.0390 & 1.0000 & & \\
\hline \multicolumn{15}{|l|}{ Constraints } \\
\hline \multicolumn{15}{|l|}{ (HC) } \\
\hline 11.Pervasiveness & 0.32 & 0.47 & -0.0547 & -0.2395 & -0.2301 & -0.0728 & 0.0449 & -0.0796 & -0.1155 & -0.0297 & 0.1058 & 0.0087 & 1.0000 & \\
\hline 12.Arbitrariness & 0.08 & 0.28 & 0.0731 & 0.0120 & 0.0145 & 0.0804 & -0.0280 & -0.0126 & 0.0269 & 0.0486 & -0.0528 & -0.0669 & 0.0470 & 1.000 \\
\hline
\end{tabular}

$\mathrm{N}=463$, Correlation greater than or equal to 0.08 is significant $(p<0.05)$.

Table 2 presents the results of a logistic regression analysis. Model 1 represents 80 percent model in which uses 80 percent as a cut-off threshold differentiating joint ventures from wholly owned subsidiaries while model 2 shows 95 percent model. Model 1A displays the results for the logistic regression with only control variables as a base model. Model 1B introduces main variables such as pervasiveness and arbitrariness of corruption and corruption distance between the home and the host country, and Model $1 \mathrm{C}$ adds the interaction term between the two dimensions of corruption. For the interaction, measures of pervasiveness and arbitrariness are centered. The increase of the pseudo R-square and Chi-square indicate that the main model shows the greater explanatory power over the base model.

Table 2. Logit Regression for mode of entry (WOS) for MNEs

\begin{tabular}{lllllll}
\hline Variables & Model 1A & Model 1B & Model 1C & Model 2A & Model 2B & Model 2C \\
\hline Political Stability & 0.176 & 0.132 & 0.384 & $0.527^{\dagger}$ & 0.477 & $0.684^{\dagger}$ \\
& $(0.287)$ & $(0.296)$ & $(0.319)$ & $(0.326)$ & $(0.332)$ & $(0.361)$ \\
GDP per Capita & 0.000 & 0.000 & 0.000 & 0.000 & 0.000 & 0.000 \\
& $(0.000)$ & $(0.000)$ & $(0.000)$ & $(0.000)$ & $(0.000)$ & $(0.000)$ \\
FDI Inflows & $0.138^{* * *}$ & $0.159^{* * *}$ & $0.146^{* * *}$ & $0.133^{* * *}$ & $0.148^{* * *}$ & $0.138^{* *}$ \\
\hline
\end{tabular}




\begin{tabular}{|c|c|c|c|c|c|c|}
\hline & $(0.040)$ & $(0.044)$ & $(0.045)$ & $(0.041)$ & $(0.043)$ & $(0.045)$ \\
\hline \multirow[t]{2}{*}{ Industry } & 0.358 & 0.361 & 0.382 & $0.531 *$ & $0.533^{*}$ & $0.607 *$ \\
\hline & $(0.247)$ & $(0.253)$ & $(0.267)$ & $(0.272)$ & $(0.276)$ & $(0.294)$ \\
\hline \multirow[t]{2}{*}{ Firm Age } & 0.002 & 0.003 & 0.003 & 0.005 & 0.004 & 0.005 \\
\hline & $(0.007)$ & $(0.007)$ & $(0.007)$ & $(0.008)$ & $(0.008)$ & $(0.008)$ \\
\hline \multirow[t]{2}{*}{ Firm Size } & -0.050 & -0.051 & -0.046 & -0.031 & -0.030 & -0.006 \\
\hline & $(0.076)$ & $(0.078)$ & $(0.082)$ & $(0.083)$ & $(0.084)$ & $(0.088)$ \\
\hline \multirow[t]{2}{*}{ Foreign Operation } & $0.558^{*}$ & $0.605^{* *}$ & $0.636^{* *}$ & $0.460^{\dagger}$ & $0.483^{\dagger}$ & $0.477^{\dagger}$ \\
\hline & $(0.230)$ & $(0.237)$ & $(0.256)$ & $(0.246)$ & $(0.251)$ & $(0.271)$ \\
\hline \multirow[t]{2}{*}{ Government Ownership } & $1.866^{* * *}$ & $1.990 * * *$ & $1.882 * * *$ & $2.532 * * *$ & $2.610 * * *$ & $2.518 * * *$ \\
\hline & $(0.413)$ & $(0.420)$ & $(0.433)$ & $(0.620)$ & $(0.622)$ & $(0.632)$ \\
\hline \multirow[t]{2}{*}{ Legal Constraints (HC) } & 0.228 & 0.196 & 0.309 & 0.331 & 0.286 & 0.409 \\
\hline & $(0.320)$ & $(0.326)$ & $(0.347)$ & $(0.337)$ & $(0.341)$ & $(0.362)$ \\
\hline \multirow[t]{2}{*}{ Pervasiveness } & & -0.359 & -0.379 & & -0.409 & $-0.534^{\dagger}$ \\
\hline & & $(0.242)$ & $(0.273)$ & & $(0.263)$ & $(0.302)$ \\
\hline \multirow[t]{2}{*}{ Arbitrariness } & & $0.794 *$ & $0.843^{\dagger}$ & & 0.314 & 0.241 \\
\hline & & $(0.392)$ & $(0.458)$ & & $(0.413)$ & $(0.471)$ \\
\hline \multirow[t]{2}{*}{ MNEs from more corrupt } & & $-2.711 * *$ & $-2.677^{*}$ & & $-2.147 *$ & $-2.103 *$ \\
\hline & & $(1.086)$ & $(1.085)$ & & $(1.082)$ & $(1.087)$ \\
\hline \multirow[t]{2}{*}{ Pervs. * Arbit. } & & & -0.207 & & & 0.285 \\
\hline & & & $(0.659)$ & & & $(0.695)$ \\
\hline Pseudo R2 & 0.140 & 0.171 & 0.176 & 0.162 & 0.181 & 0.190 \\
\hline$\Delta$ Pseudo R2 & & 0.031 & 0.005 & & 0.019 & 0.009 \\
\hline Likelihood Ratio & $84.61 * * *$ & $103.03 * * *$ & 96.15 & $87.81 * * *$ & $98.04 * * *$ & 92.74 \\
\hline Observations & 463 & 463 & 415 & 463 & 463 & 415 \\
\hline
\end{tabular}

${ }^{\dagger} p<.10, * p<0.05 ; * * p<0.01 ; * * * p<0.001$ (2-tailed).

The values shown in each block are the unstandardized regression coefficients B.

Standard errors are in parenthesis.

Model 1: WOS (>80), Model 2: WOS (>95).

Interpretation of the results is based on the 80 percent model which provides slightly more significant results. Hypothesis 1 predicts that as the level of arbitrariness of corruption rises, an MNE is more or less likely to choose wholly owned subsidiaries as their governance forms or entry modes. Model 1B shows positive relationship between arbitrariness and wholly owned subsidiaries' form of governance and it is significant at 0.05 level. It suggests that hypothesis $1 \mathrm{~b}$ is supported. Hypothesis 2 proposes that as the level of pervasiveness of corruption rises, an MNE is more or less likely to choose joint ventures as their governance forms or entry modes. Model 1B show negative associations between pervasiveness and the governance form of wholly owned subsidiaries but it does not reach a significant level. Therefore, I suggest that the prediction of hypothesis $2 \mathrm{~b}$ is consistent with the results but it is not significant. Hypothesis 3 argues that the higher the difference level of corruption between host and home countries, an MNE is more or less likely to choose joint ventures as their governance forms or entry modes. As model 1B shows, it is negative and significant $(\mathrm{p}<0.01)$. That is, an MNE coming from more corrupt countries, which means lower level of difference in their corruption between host and home countries, is more likely to adopt joint venture form of governance. Thus, it supports hypothesis $3 \mathrm{~b}$.

Some of control variables warrant some attention as well. Through all models, foreign experience, FDI inflows and government ownership consistently show the positive relationship with the WOS form of governance. In addition, the results of probit regression analysis are quite identical. 
Table 3. Probit Regression for mode of entry (WOS) for MNEs

\begin{tabular}{|c|c|c|c|c|c|c|}
\hline Variables & Model 1A & Model 1B & Model 1C & Model 2A & Model 2B & Model 2C \\
\hline \multirow[t]{2}{*}{ Political Stability } & 0.114 & 0.100 & 0.251 & $0.341^{\dagger}$ & $0.319^{\dagger}$ & $0.436^{*}$ \\
\hline & $(0.173)$ & $(0.178)$ & $(0.190)$ & $(0.195)$ & $(0.198)$ & $(0.213)$ \\
\hline \multirow[t]{2}{*}{ GDP per Capita } & 0.000 & 0.000 & 0.000 & 0.000 & 0.000 & 0.000 \\
\hline & $(0.000)$ & $(0.000)$ & $(0.000)$ & $(0.000)$ & $(0.000)$ & $(0.000)$ \\
\hline \multirow[t]{2}{*}{ FDI Inflows } & $0.084 * * *$ & $0.094 * * *$ & $0.085^{* *}$ & $0.082 * * *$ & $0.089 * * *$ & $0.082 * *$ \\
\hline & $(0.025)$ & $(0.026)$ & $(0.027)$ & $(0.025)$ & $(0.026)$ & $(0.027)$ \\
\hline \multirow[t]{2}{*}{ Industry } & 0.205 & 0.200 & 0.212 & $0.305^{*}$ & $0.298^{\dagger}$ & $0.338^{*}$ \\
\hline & $(0.149)$ & $(0.151)$ & $(0.159)$ & $(0.159)$ & $(0.161)$ & $(0.170)$ \\
\hline \multirow[t]{2}{*}{ Firm Age } & 0.002 & 0.002 & 0.002 & 0.003 & 0.003 & 0.003 \\
\hline & $(0.004)$ & $(0.004)$ & $(0.004)$ & $(0.005)$ & $(0.005)$ & $(0.005)$ \\
\hline \multirow[t]{2}{*}{ Firm Size } & -0.032 & -0.032 & -0.028 & -0.024 & -0.022 & -0.009 \\
\hline & $(0.046)$ & $(0.047)$ & $(0.049)$ & $(0.049)$ & $(0.049)$ & $(0.051)$ \\
\hline \multirow[t]{2}{*}{ Foreign Operation } & $0.351^{* *}$ & $0.379^{* *}$ & $0.400^{* *}$ & $0.280 *$ & $0.301 *$ & $0.297^{\dagger}$ \\
\hline & $(0.138)$ & $(0.141)$ & $(0.152)$ & $(0.147)$ & $(0.149)$ & $(0.161)$ \\
\hline \multirow[t]{2}{*}{ Government Ownership } & $1.071 * * *$ & $1.151^{* * *}$ & $1.096 * * *$ & $1.386^{* * *}$ & $1.439 * * *$ & $1.403 * * *$ \\
\hline & $(0.222)$ & $(0.227)$ & $(0.237)$ & $(0.298)$ & $(0.301)$ & $(0.312)$ \\
\hline \multirow[t]{2}{*}{ Legal Constraints (HC) } & 0.131 & 0.110 & 0.179 & 0.191 & 0.162 & 0.236 \\
\hline & $(0.195)$ & $(0.198)$ & $(0.211)$ & $(0.203)$ & $(0.205)$ & $(0.217)$ \\
\hline \multirow[t]{2}{*}{ Pervasiveness } & & -0.207 & -0.223 & & -0.216 & $-0.286^{\dagger}$ \\
\hline & & $(0.143)$ & $(0.162)$ & & $(0.153)$ & $(0.175)$ \\
\hline \multirow[t]{2}{*}{ Arbitrariness } & & $0.459^{*}$ & $0.481^{\dagger}$ & & 0.174 & 0.129 \\
\hline & & $(0.231)$ & $(0.272)$ & & $(0.241)$ & $(0.275)$ \\
\hline \multirow[t]{2}{*}{ MNEs from more corrupt } & & $-1.500 * *$ & $-1.498^{*}$ & & $-1.179^{*}$ & $-1.152 *$ \\
\hline & & $(0.534)$ & $(0.539)$ & & $(0.534)$ & $(0.538)$ \\
\hline \multirow[t]{2}{*}{ Pervs. * Arbit. } & & & -0.104 & & & 0.165 \\
\hline & & & $(0.394)$ & & & $(0.414)$ \\
\hline Pseudo R2 & 0.140 & 0.170 & 0.176 & 0.165 & 0.183 & 0.192 \\
\hline$\Delta$ Pseudo R2 & & 0.030 & 0.006 & & 0.018 & 0.009 \\
\hline Likelihood Ratio & $84.73 * * *$ & $102.80 * * *$ & 95.90 & $89.27 * * *$ & $99.04 * * *$ & 93.55 \\
\hline Observations & 463 & 463 & 415 & 463 & 463 & 415 \\
\hline
\end{tabular}

${ }^{\dagger} p<.10,{ }^{*} p<0.05 ; * * p<0.01 ; * * * p<0.001$ (2-tailed).

The values shown in each block are the unstandardized regression coefficients B.

Standard errors are in parenthesis.

Model 1: WOS (> 80), Model 2: WOS (>95).

The results of multinomial logit analysis indicate almost identical explanations. By contrasting with minority-owned joint venture form of governance, majority-owned joint venture form of governance shows similar results to those of logit regression analysis. As Model 2B shows, hypothesis $1 \mathrm{~b}$ is supported but it is marginally significant $(p<0.1)$, hypotheses $3 b$ is strongly supported, and hypothesis 2 is not supported.

Table 4. Multinomial Logit Regression for mode of entry for MNEs

\begin{tabular}{lllllll}
\hline Variables & Model 1A & Model 1B & Model 1C & Model 2A & Model 2B & Model 2C \\
\hline \multirow{3}{*}{ Political Stability } & $\mathrm{J} / \mathrm{V}$ & Majority & WOS & $\mathrm{J} / \mathrm{V}$ & Majority & WOS \\
& 0.301 & -0.400 & 0.135 & 0.327 & -0.399 & 0.077 \\
GDP per Capita & $(0.548)$ & $(0.315)$ & $(0.376)$ & $(0.552)$ & $(0.320)$ & $(0.381)$ \\
& 0.000 & 0.000 & $0.000^{\dagger}$ & 0.000 & 0.000 & 0.000 \\
FDI Inflows & $(0.000)$ & $(0.000)$ & $(0.000)$ & $(0.000)$ & $(0.000)$ & $(0.000)$ \\
\hline
\end{tabular}




\begin{tabular}{|c|c|c|c|c|c|c|}
\hline & $(0.099)$ & $(0.055)$ & $(0.056)$ & $(0.102)$ & $(0.057)$ & $(0.059)$ \\
\hline \multirow[t]{2}{*}{ Industry } & 0.089 & $-0.756 * *$ & 0.272 & 0.082 & $-0.751^{*}$ & 0.256 \\
\hline & $(0.447)$ & $(0.277)$ & $(0.318)$ & $(0.452)$ & $(0.281)$ & $(0.325)$ \\
\hline \multirow[t]{2}{*}{ Firm Age } & -0.030 & 0.000 & -0.007 & -0.032 & 0.000 & -0.008 \\
\hline & $(0.028)$ & $(0.007)$ & $(0.009)$ & $(0.029)$ & $(0.007)$ & $(0.010)$ \\
\hline \multirow[t]{2}{*}{ Firm Size } & $-0.318^{*}$ & -0.132 & -0.149 & $-0.319 *$ & -0.130 & -0.149 \\
\hline & $(0.149)$ & $(0.085)$ & $(0.097)$ & $(0.151)$ & $(0.087)$ & $(0.099)$ \\
\hline \multirow[t]{2}{*}{ Foreign Operation } & -0.220 & -0.317 & $0.516^{\dagger}$ & -0.179 & -0.274 & $0.556^{*}$ \\
\hline & $(0.450)$ & $(0.274)$ & $(0.286)$ & $(0.451)$ & $(0.279)$ & $(0.293)$ \\
\hline \multirow[t]{2}{*}{ Government Ownership } & 0.259 & $0.555^{\dagger}$ & $2.877 * * *$ & 0.234 & $0.637^{*}$ & $2.987 * * *$ \\
\hline & $(0.564)$ & $(0.301)$ & $(0.753)$ & $(0.569)$ & $(0.310)$ & $(0.757)$ \\
\hline \multirow[t]{2}{*}{ Legal Constraints (HC) } & -0.086 & -0.356 & 0.261 & -0.184 & -0.392 & 0.200 \\
\hline & $(0.595)$ & $(0.392)$ & $(0.386)$ & $(0.599)$ & $(0.395)$ & $(0.394)$ \\
\hline \multirow[t]{2}{*}{ Pervasiveness } & & & & 0.093 & 0.034 & -0.391 \\
\hline & & & & $(0.410)$ & $(0.260)$ & $(0.305)$ \\
\hline \multirow[t]{2}{*}{ Arbitrariness } & & & & -0.747 & $0.763^{\dagger}$ & 0.684 \\
\hline & & & & $(1.081)$ & $(0.437)$ & $(0.515)$ \\
\hline \multirow[t]{2}{*}{ MNEs from more corrupt } & & & & -1.037 & $-1.768 * *$ & $-2.818^{*}$ \\
\hline & & & & $(1.105)$ & $(0.744)$ & $(1.129)$ \\
\hline Pseudo R2 & & 0.1097 & & & 0.1278 & \\
\hline$\Delta$ Pseudo R2 & & & & & 0.0181 & \\
\hline Likelihood Ratio & & $129.03 * * *$ & & & $150.43 * * *$ & \\
\hline Observations & & 463 & & & 463 & \\
\hline
\end{tabular}

${ }^{\dagger} p<.10,{ }^{*} p<0.05 ; * * p<0.01 ; * * * p<0.001$ (2-tailed)

The values shown in each block are the unstandardized regression coefficients B.

Standard errors are in parenthesis.

Model 1: the base model, Model 2: the full model.

\section{Discussion and Conclusion}

The study proposes exactly opposite, competing hypotheses based on the well-established theories such as transaction cost economics (TCE) and real options (RO) perspective. Empirical results suggest that TCE predictions are generally supported across the hypotheses. In particular, this study finds that an MNE is more likely to adopt wholly owned subsidiaries in highly arbitrary environment of corruption whereas they intend to cope with a joint venture form of governance under highly pervasive corruption environment. Consistently, an MNE which has more experience with corruption tends to adopt a joint venture form of governance. These findings are diametrically conflicting with real options explanation and institutional perspective.

Considering the elusiveness of hybrid form of governance in the field of international business and management, the study further requests the need for more elaborate studies on this stream of research to address such conflicts between the theories. Adding on the two theories, TCE and RO perspective, adopted by this study, future studies could incorporate other theoretical explanations to address such conflicts. For example, the results of this study are parallel with the cases in emerging and transition economies, arguing that firms may benefit from early investment through acquisition to capture untapped growth opportunities (Peng, 2000). The study by Uhlrehbruck et al. (2006), which is theorized by institutional theory, presents opposite results in the same setting of transition economies. An alternative explanation on such conflicting outcomes could be found in different industry contexts. Their research is based on telecommunication industry where requires heavy investment on infrastructure and, generally, the state is involved in ownership and management in transition economies. These characteristics of telecommunication industry may lead to different results from this study. According to TCE, when the intellectual property (IP) regime is weak and it is difficult to define and enforce intellectual property rights, firms will intend to adopt a more hierarchical governance mode that offers more protection (Teece, 1986).

The study empirically examines the propositions raised by Rodiguez et al (2005), being the first attempt to verify them with a full reflection of their frameworks: pervasiveness and arbitrariness. The study provides confident evidence for this construct to be utilized in the studies on corruption in the sense that it better captures the nature 
of corruption in a country than a single index measure of corruption. Moreover, corresponding to the current research trend in corruption literature, the study illuminates the heterogeneous characteristics of firms' decisions and behaviors as to how to play with corruption and how to effectively make a decision under a corruption environment.

This study also shed a new light on the future directions of research. First, the relationship between corruption and ownership structure is not stable over time (Boeker, 1989; Miller \& Friesen, 1982; Barnett \& Burgelman, 1996). As Williamson (1991) points out, joint venture form of governance would be temporal and could change over time. Kogut and Kulatilaka (1994) also argue that joint venture form does not last very long. It suggests that it needs to theorize and test the dynamic aspects of the phenomena (Bergh and Holbein, 1997). Although this study examines such dynamics with interaction effects of MNEs' age in transition economies, it is needed a finer-grained research design for capturing such dynamics of governance structure over time.

Secondly, Anderson and Gatignon (1986) suggest that environmental unpredictability may play a crucial role when asset specificity is high, amplifying the need for control. It implies that exogenous uncertainty would have an interaction with asset specificity. Therefore, when it examines the effects of exogenous uncertainty on the entry mode, the construct of asset specificity needs to be controlled or to be investigated as an interaction term. The future research may pursue this direction of inquiries.

\section{References}

Ades, A., \& Di Tella, R. (1999). Rents, Competition, and Corruption. The American Economic Review, 89, 982-993. https://doi.org/10.1257/aer.89.4.982

Ahlstrom, D., \& Bruton, G. D. (2001). Learning from successful local private firms in China: Establishing legitimacy. Academy of Management Executive, 15(4), 72-83. https://doi.org/10.5465/ame.2001.5897661

Anderson, E., \& Gatignon, H. (1986). Modes of foreign entry: A transaction cost analysis and propositions. Journal of International Business Studies, 17, 1-26. https://doi.org/10.1057/palgrave.jibs. 8490432

Ashforth, B., \& Anand, V. (2003). The normalization of corruption in organizations. Research in Organizational Behavior, 25, 1-52. https://doi.org/10.1016/s0191-3085(03)25001-2

Barreto, R. (2000). Endogenous corruption in a neoclassical growth model. European Economic Review, 44, 35-60. https://doi.org/10.1016/s0014-2921(98)00052-x

Baum, J., \& Oliver, C. (1991). Institutional linkages and organizational mortality. Administrative Science Quarterly, 36, 187-218. https://doi.org/10.2307/2393353

Blackburn, K., Bose, N., \& Haque, E. (2004). Endogenous corruption in economic development. Research paper 2004-16. Nottingham University, UK. https://doi.org/10.2139/ssrn.761705

Bowman, E., \& Hurry, D. (1993). Strategy 'through the option lens: An integrated view of resource investments and the incremental-choice process. Academy of Management Review, 18, 760-782. https://doi.org/10.2307/258597

Brothers, L. E., Gao, Y., \& Mcnicol, J. P. (2008). Corruption and market attractiveness influences on different types of FDI. Strategic Journal of Management, 29, 673-680. https://doi.org/10.1002/smj.669

Buckley, P., \& Casson, M. (1976). The future of the multinational enterprise. London: Macmillan. https://doi.org/10.1007/978-1-349-02899-3_3

Campos, J. E., Lien, D., \& Pradhan, S. (1999). The impact of corruption on investment: Predictability matters. World Development, 27, 1059-1067. https://doi.org/10.1016/s0305-750x(99)00040-6

Carroll G. R., \& Teece, D. J. (1999). Firms, markets, and hierarchies: introduction and overview. In Carroll G. R., \& Teece, D. J. (Eds.), Firms, Markets, and Hierarchies: The Transaction Cost Economics Perspective. London: Oxford University Press.

Carter, R., \& Hodgson, G. (2006). The impact of empirical tests of transaction cost economics on the debate on the nature of the firm. Strategic Management Journal, 27, 461-476. https://doi.org/10.1002/smj.531

Caves, R. (1982). Multinational enterprise and economic analysis. Cambridge: Cambridge University Press. https://doi.org/10.1017/cbo9780511619113.002

Coleman, J. S. (1994). Foundations of Social Theory. London: Harvard University Press.

David, R. J., \& Han, S. (2004). A Systematic Assessment of the Empirical Support for Transaction Cost Economics. Strategic Management Journal, 25, 39-58. https://doi.org/10.1002/smj.359 
Davis, P., Desai, A., \& Francis, J. (2000). Mode of international entry: An isomorphism perspective. Journal of International Business Studies, 31, 239-258. https://doi.org/10.1057/palgrave.jibs.8490904

Delios, A., \& Beamish, B. (1999). Ownership strategy of Japanese firms: Transactional, institutional and experience influences. Strategic Management Journal, 20, 915-933. https://doi.org/10.1002/(sici)1097-0266(199910)20:10\%3C915::aid-smj51\%3E3.0.co;2-0

Demsetz, H. (1968). Why regulate utilities? Journal of Law and Economics, 11, 55-66. https://doi.org/10.1007/978-1-349-15486-9_10

DiMaggio, P., \& Powell, W. (1983). The Iron Cage Revisited: Institutional Isomorphism and Collective Rationality in Organizational Fields. American Sociological Review, 48, 147-160. https://doi.org/10.2307/2095101

Dixit, A. K., \& Pindyck, R. S. (1994). Investment Under Uncertainty. Princeton University Press: Princeton, NJ.

Dunning, J. (1977). The location of economic activity and the multinational enterprise: Search for an eclectic approach. In B. Ohlin, P. Hesselborn \& P. Wiskman (Eds.), The International Allocation of Economic Activity. (pp. 395-418). London: Macmillan. https://doi.org/10.1007/978-1-349-03196-2

Eden, R., \& Miller, S. (2004). Distance matters: Liability of foreignness, institutional distance and ownership strategy. Theories of the Multinational Enterprise: Diversity, Complexity, and Relevance. Advances in International Management, 16, 187-221. https://doi.org/10.1016/s0747-7929(04)16010-1

Folta, T., \& Miller, K. (2002). Real options in equity partnerships. Strategic Management Journal, 23, 77-88. https://doi.org/10.1002/smj.209

Fukuyama, F. (1996). Trust: The social virtues and the creation of property. Free Press.

Gatignon, H., \& Anderson, E. (1988). The multinational corporation's degree of control over foreign subsidiaries: an empirical test of a transaction cost explanation. Journal of Law, Economics, \& Organizations, 4, 305-336.

Glynn, M. A., \& Abzug, R. (2002). Institutional identity: Symbolic isomorphism and organizational names. Academy of Management Journal, 45, 267-280. https://doi.org/10.2307/3069296

Gomez-Casseres, B. (1989). Ownership structure of foreign subsidiaries. Journal of Economic Behavior and Organization, 11, 1-25. https://doi.org/10.1016/0167-2681(89)90061-9

Gordon, K., \& Miyaki, M. (2001). Business approaches to combating bribery: A study of codes of conduct. Journal of Business Ethics, 34, 161-173. https://doi.org/10.1787/082658020086

Habib, M., \& Zurawicki, L. (2002). Corruption and foreign direct investment. Journal of International Business Studies, 33, 291-308.

Hausman, J., \& McFadden, D. (1984). A specification test for the multinomial logit model. Econometrica, 52, 1219-1240. https://doi.org/10.2307/1910997

Henisz, W. (2000). The institutional environment for multinational investment. Journal of Law, Economics, \& Organizations, 16, 334-364. https://doi.org/10.1093/jleo/16.2.334

Hennart, J. (1991). The transaction cost theory of joint ventures: an empirical study of Japanese subsidiaries in the United States. Management Science, 37, 483-497. https://doi.org/10.1287/mnsc.37.4.483

Hennart, J. F. (1982). A theory of multinational enterprise. Ann Arbor, MI: University of Michigan Press.

Hennart, J. F. (1988). A transaction costs theory of equity joint ventures. Strategic Management Journal, 9 , 361-374. https://doi.org/10.1002/smj.4250090406

Hennart, J., \& Park, Y. R. (1993). Greenfield vs. acquisition: The strategy of Japanese investors in the United States. Management Science, 39, 1054-1070. https://doi.org/10.1287/mnsc.39.9.1054

Hill, C., \& Kim, W. (1988). Searching for a dynamic theory of the multinational enterprise: A transaction cost model. Strategic Management Journal, 9, 93-104. https://doi.org/10.1002/smj.4250090710

Hill, C., Hwang, P., \& Kim, W. (1990). An eclectic theory of the choice of international entry mode. Strategic Management Journal, 11, 117-128. https://doi.org/10.1002/smj.4250110204

Holtbrugge, D., \& Baron, A. (2013). Market entry strategies in emerging markets: An institutional study in the BRIC countries. Thunderbird International Business Review, 55(3), 237-252. https://doi.org/10.1002/tie.21541 
Kogut, B. (1991). Joint ventures and the option to expand and acquire. Management Science, 37, 19-33. https://doi.org/10.1287/mnsc.37.1.19

Kogut, B., \& Kulatilaka, N. (1994). Options Thinking and Platform Investments: Investing in Opportunity. California Management Review, Winter, 52-71. https://doi.org/10.2307/41165744

Kogut, B., \& Singh, H. (1988). The effect of national culture on the choice of entry mode. Journal of International Business Studies, 19, 411-432. https://doi.org/10.1057/palgrave.jibs.8490394

Kostova, T., \& Roth, K. (2002). Adoption of an organizational practice by subsidiaries of multinational corporations: Institutional and relational effects. Academy of Management Journal, 45, 215-233. https://doi.org/10.2307/3069293

Kostova, T., \& Zaheer, S. (1999). Organizational legitimacy under conditions of complexity: The case of the multinational enterprise. Academy of Management Review, 24, 64-81. https://doi.org/10.2307/259037

Makino, S., \& Beamish, P. (1998). Performance and survival of joint ventures with non-conventional ownership $\begin{array}{lllll}\text { structures. Journal of International Business Studies, 29, 797-818. } & \text {. }\end{array}$ https://doi.org/10.1057/palgrave.jibs.8490054

Mauro, P. (1995). Corruption and Growth. Quarterly Journal of Economics, 110, 681-712.

Mauro, P. (1998). Corruption and the composition of government expenditure. Journal of Public Economics, 69, 263-279. https://doi.org/10.1016/s0047-2727(98)00025-5

McGrath, R., \& Nerkar, A. (2004). Real options reasoning and a new look at the R\&D investment strategies of pharmaceutical firms. Strategic Management Journal, 25, 1-22. https://doi.org/10.1002/smj.358

Meyer, K. E., Estrin, S., Bhaumik, S. K., \& Peng, M. W. (2009). Institutions, resources, and entry strategies in emerging economies. Strategic Management Journal, 30, 61-80. https://doi.org/10.1002/smj.720

Miller, K., \& Folta, T. (2002). Option value and entry timing. Strategic Management Journal, 23, 655-665. https://doi.org/10.1002/smj.244

Milovanovic, M. (2002). Endogenous corruption in privatized companies. Working paper.

North, D. C. (1990). Institutions, Institutional Change and Economic Performance. Cambridge, England, Cambridge University Press. https://doi.org/10.1017/cbo9780511808678

Oldenburg, P. (1987). Middlemen in third-world corruption. World Politics, 39, 508-535. https://doi.org/10.2307/2010290

Oliver, C. (1991). Strategic responses to institutional process. Academy of Management Review, 16, 145-179. https://doi.org/10.2307/258610

Parkhe A. (1993). Strategic alliance structuring: A game theoretic and transaction cost examination of interfirm cooperation. Academy of Management Journal, 36, 794-829. https://doi.org/10.2307/256759

Reuer J., \& Leiblein, M. (2000). Downside risk implications of multinationality and international joint ventures. Academy of Management Journal, 43, 203-214. https://doi.org/10.2307/1556377

Richman, B. D., \& Macher, J.T. (2003). Transaction Cost Economics: An Assessment of Empirical Research in the Social Sciences. Working Paper, mimeo. https://doi.org/10.2139/ssrn.924192

Rodriguez, P., Uhlenbruck, K., \& Eden, L. (2005). Government Corruption and the Entry Strategies of Multinationals. Academy of Management Review, 30(2), 383-396. https://doi.org/10.5465/amr.2005.16387894

Shleifer, A., \& Vishny, R. W. (1993). Corruption. Quarterly Journal of Economics, 108, 599-617.

Smarzynska, B., \& Wei, S. (2000). Corruption and Composition of Foreign Direct Investment: Firm-level Evidence. NBER Working Paper no. 7969. https://doi.org/10.3386/w7969

Stopford, J., \& Louis T. (1972). Managing the multinational enterprises. New York: Basic Books.

Tong, T. W., \& Reuer, J.J. (2007). Real options in multinational Corporations: Organizational challenges and risk implications. Journal of International Business Studies, 38(2), 215-230. https://doi.org/10.1057/palgrave.jibs. 8400260

Tong, T., Reuer, J., \& Peng, M. (2008). International joint ventures and the value of real options. Academy of Management Journal, 51(5), 1014-1029. https://doi.org/10.5465/amj.2008.34789680 
Voyer, P., \& Beamish, P. (2004). The Effect of Corruption on Japanese Foreign Direct Investment. Journal of Business Ethics, 50, 211-224. https://doi.org/10.1023/b:busi.0000024737.57926.bf

Wei, S. J. (1997). Why is corruption so much more taxing than tax? Arbitrariness kills. Working paper No. 6255, National Bureau of Economic Research, Cambridge, MA. https://doi.org/10.3386/w6255

Wei, S. J. (2000). How taxing is corruption on international investors? The Review of Economics and Statistics, 82, 1-11. https://doi.org/10.1162/003465300558533

Williamson, O. (1975). Markets and Hierarchies: Analysis and Antitrust Implications. New York, The Free Press.

Williamson, O. (1979). Transaction Cost Economics: The Governance of Contractual Relations. Journal of Law and Economics, 22, 233-261. https://doi.org/10.1086/466942

Williamson, O. (1985). The Economics of Organization: The Transaction Cost Approach. American Journal of Sociology, 87, 548-577. https://doi.org/10.1086/227496

Williamson, O. (1991). Comparative Economic Organization: The Analysis of Discrete Structural Alternatives. Administrative Science Quarterly, 36, 269-96. https://doi.org/10.2307/2393356

Williamson, O. E. (1994). Transaction costs Economics and Organization Theory. In The Handbook of Economic Sociology. Smelser. Neil and Swedberg. Richard. Princeton University Press. https://doi.org/10.1093/0198290969.003.0002

Xu, D., \& Shenkar, O. (2002). Institutional distance and the multinational enterprise. Academy of Management Review, 27, 608-618. https://doi.org/10.2307/4134406

$\mathrm{Xu}$, D., Yigang, P., \& Beamish, P. (2004). The effect of regulative and normative distances on MNE ownership and expatriate strategies. Management International Review, 44, 285-307.

Yiu, D., \& Makino, S. (2002). The choice between joint venture and wholly owned subsidiary: An institutional perspective. Organization Science, 13, 667-683. https://doi.org/10.1287/orsc.13.6.667.494

Zaheer, S. (1995). Overcoming the liability of foreignness. Academy of Management Journal, 38, 341-363. https://doi.org/10.2307/256683

Zaheer, S., \& Mosakowski, E. (1997). The dynamics of the liability of foreignness: A global study of survival in financial services. Strategic Management Journal, 18, 439-464. https://doi.org/10.1002/(sici)1097-0266(199706)18:6\%3C439::aid-smj884\%3E3.3.co;2-p

Zaheer, S., Priem, R., \& Rasheed, A. (2005). The antecedents and consequences of top management fraud. Journal of Management, 31, 803-828. https://doi.org/10.1177/0149206305279598

Zhao, H., Luo, Y., \& Suh, T. (2004). Transaction cost determinants and ownership-based entry mode choice: A meta-analytical review. Journal of International Business Studies, 35, 524-545. https://doi.org/10.1057/palgrave.jibs. 8400106

\section{Note}

Note 1. Eden and Miller (2004) differentiate these two concepts such that a liability of foreignness stresses the social costs of doing business abroad, whereas costs of doing business abroad includes both economic and social costs.

\section{Copyrights}

Copyright for this article is retained by the author(s), with first publication rights granted to the journal.

This is an open-access article distributed under the terms and conditions of the Creative Commons Attribution license (http://creativecommons.org/licenses/by/4.0/). 